\title{
М.В. Касіянчук
}

\section{ПРОТЕТИКА НА ІМПЛАНТАХ - ЯК ЦІЛІСНІСТЬ КОНСТРУКЦЇ̈ ІМПЛАНТОЛОГІЧНОЇ СИСТЕМИ, ВІДДАЛЕНІ РЕЗУЛЬТАТИ ЗАСТОСУВАННЯ ВЛАСНОЇ МЕТОДИКИ ПРОТЕЗУВАННЯ}

Буковинський державний медичний університет, м. Чернівці

Приватна спеціалізована лікарська практика, м. Чернівці

\begin{abstract}
Резюме. Розглянуто застосування власної методики протезування на імплантатах разом із запатентованим способом виготовлення протетичної конструкції (патент № 40621). Встановлено ефективність використання запропонованої методики на основі сучасних технологій. Представлено поєднання протезування i
\end{abstract}

Вступ. Широке застосування дентальних імплантатів мають великий показник успішності. Наприклад, J. Zöller [15] вважає, що у 86,1 \% випадків втрати зубів доцільним є застосування різних варіантів дентальної імплантації. Багаторічний практичний досвід використання внутрішньокісткових імплантатів у стоматологічних клініках відкриває нові можливості підвищення якості ортопедичного лікування пацієнтів [4, 16-18]. Використання імплантатів при дефектах зубних рядів як опірних елементів, фіксаторів і стабілізаторів протезів у переважній своїй більшості стає єдиним заходом задоволення вимог хворого щодо якості протезування; при цьому переваги знаходяться на боці внутрішньокісткових імплантатів і протетичним конструкціям із дискретним часом фіксації на них $[1,5,6,15,19,20]$. Але пропозиція виробників імплантологічних систем завершується виготовленням супраструктури [16]. Протезування на них є справою і технічними можливостями клініки (лабораторії), які часто обмежені. Поява на ринку нових імплантологічних систем не завжди дозволяє клініцистам мати можливість досягти високого естетичного результату та ефективного відновлення функції жувального апарату $[1-5,13,15,17]$. Провідними виробниками імлантологічної продукції пропонується виготовлення супраструктури i протетичної конструкції централізовано. Ця пропозиція є вартісною, і пропонується як окрема опція $[16,17,19,21]$. У зв'язку з вищенаведеним ми застосували одну з імплантологічних систем, яка має в базовій пропозиції конструктивні елементи, придатні для виготовлення протезної конструкції на імплантаті [3].

Нами розроблений, впроваджений та захищений патентом України власний метод протезування на імплантаті [7]. На рис. 1 а, б, в представлені основні лабораторні етапи виготовлення протетичної конструкції за запропонованою методикою. Вперше метод протезування на імплантатах із використанням базових елементів імплатологічної системи ми оприлюднили у 2006-му році. Імплантологічна система представлена як цілісна концепція реабілітації пацієнта при втраті дентальної імплантації як єдиного лікувальнореабілітаційнго процесу. Встановлено клінічні протипоказання до застосування запропонованої методики.

Ключові слова: імплантат, абатмент, імплантоясенні кишені, протетична реабілітація, медична навігація.

зубів із використанням дентальних імплантатів, у якій $є$ ортопедичний аспект у іiї базовій пропозиції [8].

Мета дослідження. Логітудинально визначити ефективність застосування методики протезування із застосуванням протетичної конструкції, виготовленої на основі базової пропозиції імплантологічної системи.

Матеріал і методи. Протетичні конструкції виготовлені з використанням базової пропозиції імплантологічної системи '’U-імпл', (Україна) [3, $4,7,8]$. Лабораторні роботи виконувались одним спеціалістом, з однаковим технічним забезпеченням, за нетривалий проміжок часу. Спостереження проводились у період до десяти років експлуатації протетичних конструкцій.

Вибірку склали 20 пацієнтів, яким протезування на імлантатах виконали за запропонованою методикою у 2002-2004 роках. I яким було виготовлено 30 одиниць протезування. Співвідношення чоловіки-жінки складало 1:2, середній вік пацієнтів становив $43 \pm 4$ роки. Використано дескриптивний та аналітичний дизайн дослідження із дотриманням вимог щодо проведення клінічних досліджень (поінформована згода).

Пацієнтів розподілили на дві групи: до основної ( дослідної) увійшли пацієнти (10 осіб), в яких протезування виконано за власною методикою (патент України № 23147) [7], і які мали ускладнення (злами, неадекватна зношеність протезної конструкції), косметичний дефект внаслідок процесу ремоделювання анатомічних структур коміркового відростка щелепи в приясенній ділянці тощо (рис. 3,8$)$. До контрольної (10 пацієнтів) - особи, в яких протезування виконано за власною методикою, але не має потреби в заміні ортопедичної конструкції на імплантаті (рис. 2).

Пацієнтів обох груп обстежували за стандартними схемами: вивчали анамнез, звертали увагу на загальносоматичний стан пацієнтів, оцінювали їх психоемоційний статус, мотивацію ортопедичної реабілітації, дотримання гігієни порожнини рота. У комплексному стоматологічному обстеженні пацієнтам проводили зовнішньоротовий огляд та внутрішньоротові обстеження, застосо-

(C) М.В. Касіянчук, 2013 
вували рентгенологічні методи дослідження: ортопантомографію, радіовізіографію. Визначали стан протезної конструкції (зношеність, злам, фіксацію). Виявлення прихованого запального процесу м'яких тканин проводили за тестом Шиллера-Писарєва (Ю. Писарєв, 1956).

3 метою вивчення топографії анатомічних структур у приімплантатній ділянці [14] ми застосували одну з інтерактивних методик - медичну навігацію. При цьому ми використали експериментальну версію приладу для медичної навігації власної конструкції $[5,9,10]$, у комплексі зі спеціалізованою комп'ютерною програмою [19]. Калібрування приладу проводилося за відомими, видимими, не змінними параметрами, наприклад діаметр шийки імплантата тощо. Для порівняльного аналізу використовувались архівні матеріали, (радіовізіографічні, томографічні, фотографічні, гіпсові та цифрові моделі), приватної спеціалізованої клініки, де проводилося лікування пацієнтів. Статистичну обробку результатів проводили за стандартними методами варіаційної статистики $[11,12]$ та кореляційного аналізу з використанням пакета комп'ютерних програм Statistica 6.0 for Windows та QuattroPro 12.0 for Windows. Вірогідність різниці оцінювали за критерієм Стьюдента при рівні $\mathrm{p}<0,05$.

Результати дослідження та їх обговорення. Перед практичним лікарем ставиться завдання відновити втрачені анатомічні структури коміркового відростка таким чином, щоб завершити результат успішної імплантації. Перед науковцем ставиться завдання знайти альтернативу класич-

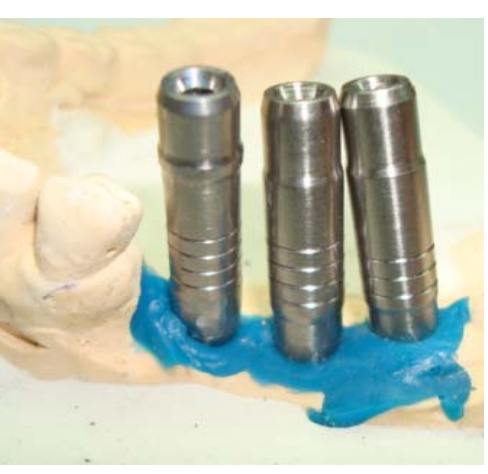

a

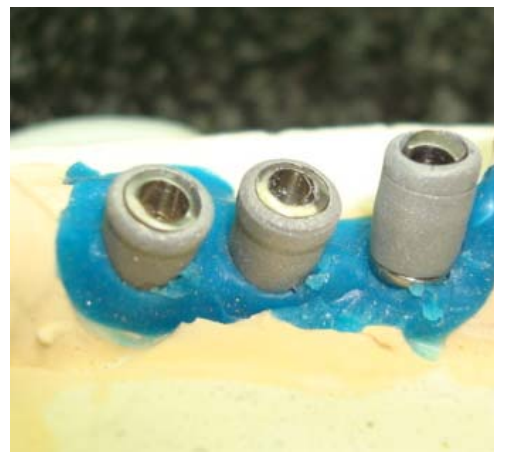

6 ним методам протезування, наприклад мостоподібні протези тощо, які б запобігали прояву запально-дистрофічних процесів у тканинах пародонта прилеглих зубів.

При порівнянні результатів спостереження за пацієнтами дослідних груп у динаміці, визначена незначна статистична різниця при огляді (рис. 5).

При подальшому спостереженні за пацієнтами до 10 років в осіб основної і контрольної групи серед скарг, у першу чергу, акцентувалась увага на періодично неприємні відчуття в яснах, потребу в спеціальній гігієні міжімплантних просторів тощо (рис. 6).

У п’яти пацієнтів дослідної групи (50\%) проводилося повторне протезування 3 причини зламу облицювання протезної конструкції. Проводячи аналіз, ми встановили причинну залежність. Злам облицювання відбувається в боковій ділянці зубів у випадку значної ширини оклюзійної поверхні протезної конструкції по відношенню до діаметра титанового каркаса протезної конструкції (рис. 3, 4) при збільшенні функціонального навантаження на протезну конструкцію, що має місце, наприклад: при втраті зубів, стиранні твердих тканин інших зубів, не раціональній реставрації тощо (рис. 7).

Проте ми не спостерігали зламів облицювання при незначній ширині оклюзійної поверхні протезної конструкції по відношенню до діаметра титанового каркаса (мак1/2), або використанні двох опорних імплантатів на одну протезну конструкцію в чотирьох пацієнтів контрольної групи $(40 \%)$ (рис. 8).

Рис.1а,б,в. Основні лабораторні етапи виготовлення протетичної конструкції

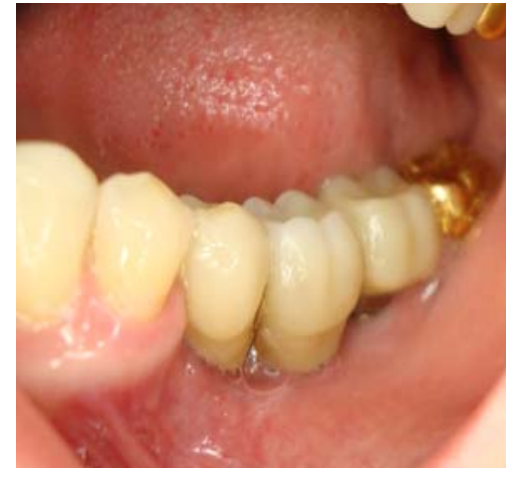

Рис.2. Клінічний приклад: контрольний огляд через 10 років

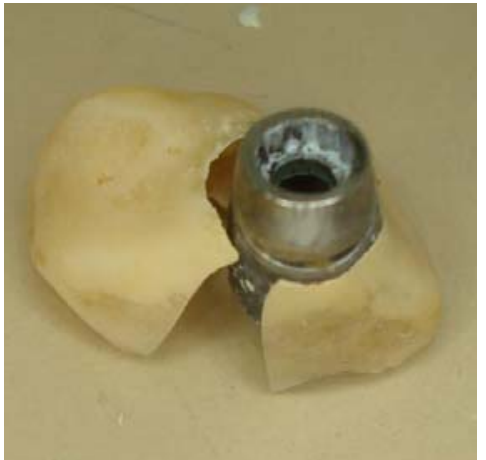

Рис.3. Клінічний приклад: злам протезної конструкції

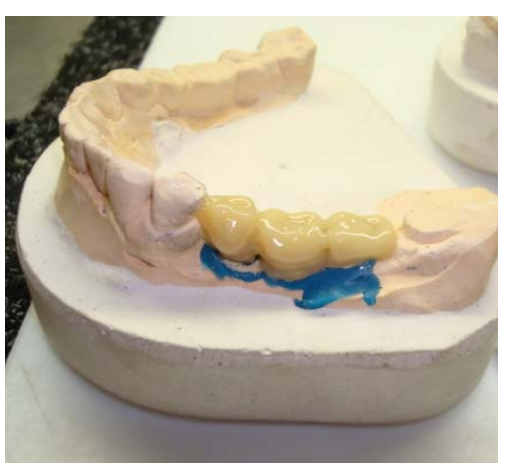

B

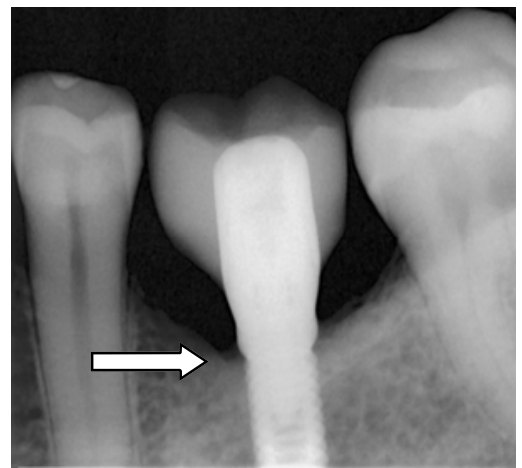

Рис.4. Клінічний приклад: ризик зламу протезної конструкції 


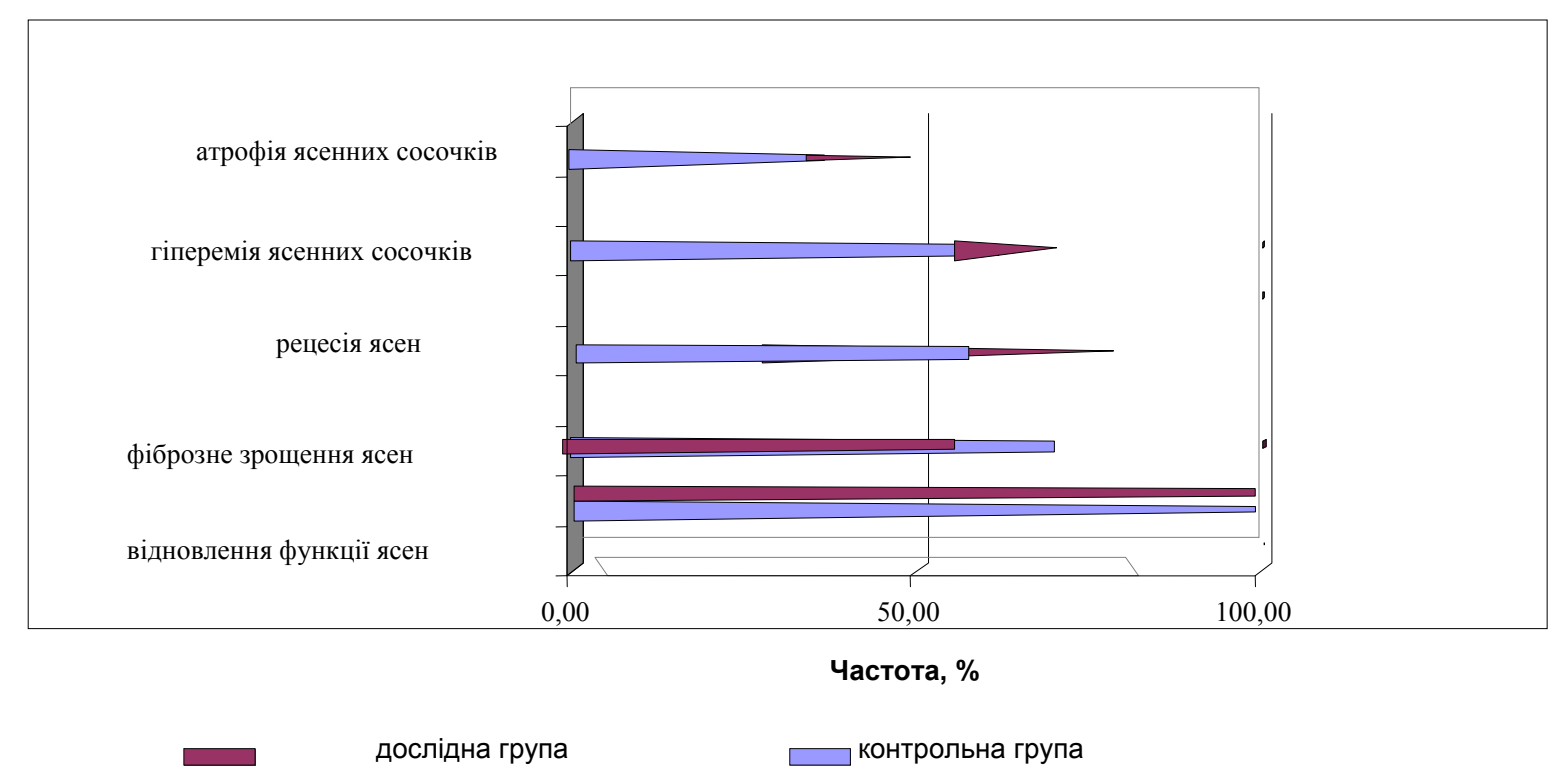

Рис. 5. Частота симптомів у динаміці післяпротезного періоду (5 років) у пацієнтів основної та дослідної групи Примітка. вірогідність різниці $\mathrm{p}<0,05)$
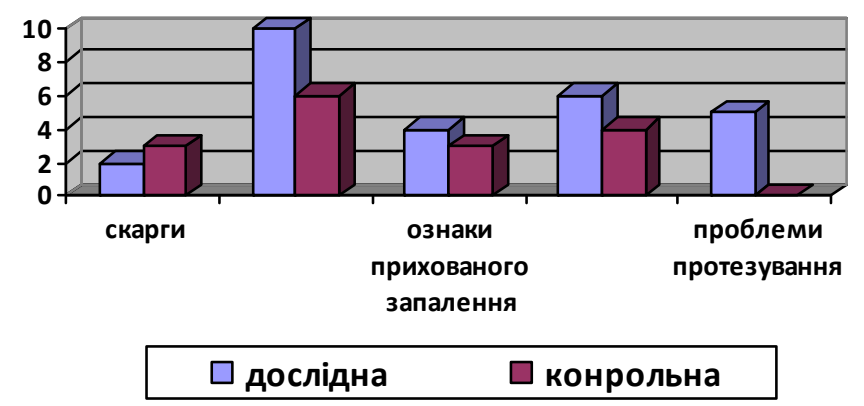

Рис. 6. Частота симптомів у динаміці після протезування (10 років) у пацієнтів основної та дослідної групи

Примітка. * - вірогідність різниці $\mathrm{p}<0,05$

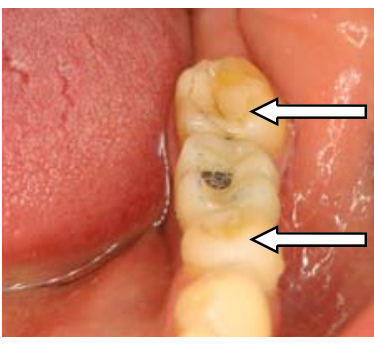

Рис. 7

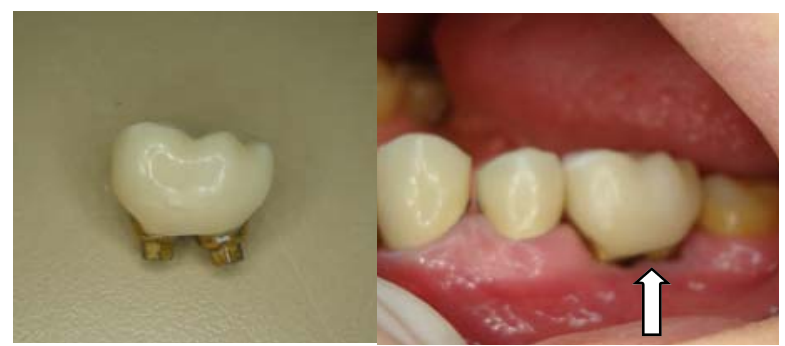

Рис. 8

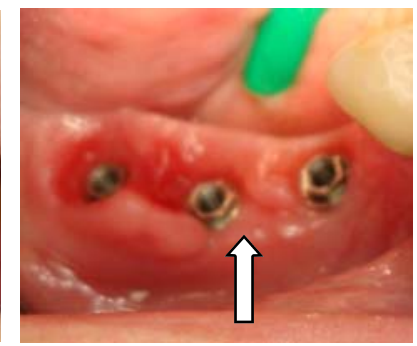

Рис. 9

Рис. 7. Клінічний приклад: збільшення функціонального навантаження на протезну конструкцію

Рис. 8. Клінічний приклад: використання двох опорних імплантатів на одну протезну конструкцію, утворення дефектів у приясенній ділянці

Рис. 9. Клінічний приклад: виявлення прихованого запального процесу

Рецесію ясен у приімлантатній ділянці ми спостерігали в обох групах із різною частотою зустрічальності (рис. 8, 9). Дефекти в приясенній ділянці, одонтогліфічні особливості ми корегували, за потреби, у лабораторних умовах, завдяки дискретності фіксації протезної конструкції, продовживши термін іiї експлуатації.
Для оцінки ефективності застосування методу протезування нами вивчено об'єктивні параметри в пацієнтів основної та контрольної групи - ширину коміркового відростка, ступінь вертикальної резорбції кісткової тканини протягом 10 років спостереження за пацієнтами. В основній та контрольній групі ширина коміркового відростка 
після протезування вірогідно не відрізнялась і складала 7,4 \pm 2 мм для обох груп та $6,8 \pm 2$ мм для обох груп $(\mathrm{p}>0,05)$ на теперішній час. Подібне спостерігається при оцінці вертикальної резорбції кісткової тканини.

Виявлення прихованого запального процесу, за тестом Шиллера-Писарєва, зафіксовано у 3 (30 \%) випадках у контрольній групі та в 4 (40\%) випадках основної (дослідної) (рис. 9).

Клінічний прояв запалення м'яких тканин усунуто застосуванням курсу лазеротерапії за відомою методикою, мінімізацією травматичного фактору. Отже, протипоказом до застосування запропонованої методики протезування на імплантатах є значна ширина оклюзійної поверхні протезної конструкції по відношенню до діаметра іiї титанового каркаса (більше 2/1). У цих випадках рекомендовано застосування двох опірних імплантатів або моделювання розширеної оклюзійної платформи, при виготовлені титанового каркаса протезної конструкції.

\section{Висновок}

Зважаючи на досвід роботи в галузі дентальної імплантології і протетики, проведеного дослідження ми прийшли до висновку, що виготовлення протетичної конструкції на остеоінтегрованому імплантаті запропонованим способом дозволяє:

1. Компенсувати втрачені функції зуба та усунути клінічну симптоматику.

2. Зменшити ризик втрати тканин у віддалений період після імплантації в ділянці окістя в приімплантатній зоні.

3. Визначити ефективність застосування та встановити протипокази до застосування запропонованої методики.

4. Прогнозувати термін використання запропонованої протетичної конструкції та можливі ускладнення при іiі застосуванні.

Перспективи подальших досліджень. Вивчення та подальша розробка цього методу в різних вікових групах дозволить прогнозовано проводити корекцію або заміну протетичної супрастуктури при збереженні діючого імплантата. Перспективно iii застосовування в навчальному процесі у ВНЗах і факультетах післядипломної освіти.

\section{Література}

1. Заблоцький Я.В. Порівняльний аналіз ускладнень ортопедичного лікування незнімними зубними протезами з опорою на природні зуби та імплантати / Я.В. Заблоцький // Імплантологія. Парадонтологія. Остеологія. - 2006. № 1. - С. 42-46.

2. Чинники ризику та шляхи їх подолання при проведенні дентальної імплантації / [Пюрик В.П., Проць Г.Б. та ін.]: матеріали III Українського міжнародного конгресу [«Стоматологічна імплантація. Остеоінтеграція»] 15-17 травня 2008p. - С. 128.

3. Угрин М.М. Досвід використання імплантатів вітчизняного виробництва при заміщенні де- фектів зубних рядів / М.М. Угрин // Акт. пробл. ортопед. стоматології. - Львів, 1996. C. 21.

4. Касіянчук М.В. Ефективність використання стандартної титанової капсули для імплантатів U-IMPL при виготовленні ортопедичних конструкцій. / М.В. Касіянчук // Імплантологія. Парадонтологія. Остеологія. - 2009. № 1. - С. 80-83.

5. Обгрунтування удосконалення технології дентальної імплантації при використанні імплантатів з розширеною платформою (на прикладі імплантатів U-IMPL) / M.B. Касіянчук, П.М. Фочук, П.Ф. Пшенічка [та ін.] // Імплантологія. Парадонтологія. Остеологія. - 2010. № 3. - С. 27-32.

6. Касіянчук М.В. Обгрунтування удосконалення методики етапу встановлення формувача ясен при дентальній імплантації (на прикладі імплантатів U-IMPL) / М.B. Касіянчук, Г.Ю. Колачова, Ю.М. Касіянчук // Імплантологія. Парадонтологія. Остеологія. - 2011. № 3. - С. 70-73.

7. Пат. 68641 Україна, МПК А61С 8/00. Прилад "Навігатор ЮК" для визначення позиціювання інструмента чи імплантату при оперативних втручаннях / Касіянчук Ю.М., Пшенічка П.Ф., Касіянчук М.В..; Заявник Касіянчук Ю.М., Пшенічка П.Ф., Касіянчук М.В. № заяви u201107759 від 20.06.2011; опубл. 10.04.2012. Бюл. № 7.

8. Касіянчук М.В. Комплексне застосування консервації коренів молярів і системи "Uimpl“, як метод попередження атрофії альвеолярного відростка нижньої щелепи / М.В. Касіянчук: матеріали II Східноєвропейської конференції з проблем стоматологічної імплантації [“Спільні стратегії в імплантології ”]. Львів, 2006 - С. 112.

9. Пат. 40621 Україна, МПК А61С 13/00. Спосіб виготовлення протетичної конструкції на імлантах U-IMPL / Касіянчук M.В., Угрин М. М.; Заявник Касіянчук М.В., Угрин М. М. № заяви u200809000 від 09.07.2008; опубл. 27.04.2009. Бюл. № 8.

10. Медична навігація, як метод оптимізації навчального процесу в клініці ортопедичної стоматології / Касіянчук М.В., Пшенічка П.Ф., Фочук П.М., Касіянчук Ю.М.: матеріали Всеукраїнської наукової конференції: [“Впровадження нових технологій за кредитномодульної системи організації навчального процесу у $\mathrm{BM}(\Phi)$ Н3 III-IV рівнів акредитації“]. - Тернопіль, 2012. - С. 314-316.

11.Гланц С. Медико-биологическая статистика: Пер. с англ. / С. Гланц. - М.: Практика, 1998. - 459 c.

12. Гублер Е.В. Применение непараметрических критериев статистики в медико-биологических исследованиях / Е.В. Гублер, А.А. Генкин. - Л., 1973. - 122 с. 
13. Callan D. Дентальные имплантаты и атрофия кости вокруг шейки имплантата / P. Donald Callan // Стоматолог. - 2000. - № 9. - С. 16-19.

14. Cooper L. Роль поверхностной топографии в создании и обслуживании кости на титановых имплантатах промышленной очистки / L.F. Cooper// Новое в стоматологии. - 2002. № 8 (108). - C. 83-92.

15. Zöller J. Curriculum Implantologi of BDIZ EDI and the University of Colonge, Germany / J. Zöller, J. Neugebauer// The University of Colonge. - 2006. - P. 40.

16. Engels H. Handbuch zum BDIZ/EDI Implant Register / Helmut B. Engels. - Nov., 2003. $630 \mathrm{p}$.
17. Marginal bone reaction to oral implants: a prospective comparative study of Astra Tech and Branemark System implants / B. Engquist, P. Astrand [et al.]. - Clin Oral implants Res, 2002. - P. 30-37.

18. Karapetian E. Immtdiate implant loadinq in auqmented upper end lover jav. / E. Karapetian, J. Neuqebauer, J. Zoller // University Colonqne,Germany. -2007. - P. 85.

19. Computer Guided Implantology \&3d medical modelling. Materialise Head lines. - 2004. № 2. - P. 7 .

20. Fast and easy 3D implant treatment plening. European Journal for Dental Implantologists. 2011. - № 3. - P. 100.

\section{ПРОТЕТИКА НА ИМПЛАНТАТАХ - КАК ЦЕЛОСТНОСТЬ КОНСТРУКЦИИ ИМПЛАНТОЛОГИЧЕСКИЙ СИСТЕМЫ, ОТДАЛЕННЫЕ РЕЗУЛЬТАТЫ ПРИМЕНЕНИЯ СОБСТВЕННОЙ МЕТОДИКИ ПРОТЕЗИРОВАНИЯ}

\section{М.В. Касиянчук}

Резюме. Рассмотрено применение собственной методики протезирования на имплантатах, вместе с запатентованным способом изготовления протетической конструкции (патент № 40621). Установлена эффективность использования предложенной методики на основе современных технологий. Представлено единение протезирования и дентальной имплантации, как единого лечебно-реабилитационнго процесса. Установлено клинические противопоказания к применению предложенной методики.

Ключевые слова: имплантат, аббатмент, имплантодесневые карманы, протетическая реабилитация, медицинская навигация.

\section{PROSTHETICS ON IMPLANTS AS AN INTEGRITY OF THE CONSTRUCTION OF THE IMPLANTOLOGIC SYSTEM, THE LONG-TERM RESULTS OF APPLYING THE AUTHOR'S OWN METHOD OF PROSTHETICS}

\section{M.V. Kasiyanchuk}

Abstract The use of the author's own technique of prosthetics on implants along with a patent method of manufacturing prosthetic construction (patent №40621). The efficacy of using the proposed technique on the basis of modern technologies has been established. A combination of prosthetics and dental implantation as an integral medicative - rehabilitative process is presented. Clinical contraindications to the use of the suggested procedure have been established.

Key words: implant, abutment, implantogingival pockets, prosthetic rehabilitation, medical navigation.

Bukovinian State Medical University (Chernivtsi) Private Specialized Medical Practice (Chernivtsi) 